\title{
The Impact of Internal Control Quality on CFO Turnover
}

\author{
Ya-Fang Wang (Corresponding author) \\ Department of Accounting, Providence University \\ Taichung City, Taiwan \\ E-mail: yfwang2@pu.edu.tw
}

\author{
Yu-Ting Huang \\ Ph. D. Program in Business, Chung Yuan Christian University \\ Chung Li City, Taiwan \\ E-mail: g10104602@cycu.edu.tw
}

Received: May 8, 2013 Accepted: May 16, 2013 Published: June 1, 2013

doi:10.5296/ajfa.v5i1.3641ＵRL: http://dx.doi.org/10.5296/ajfa.v5i1.3641

\begin{abstract}
Accurate financial reports are crucial for regulators, auditors, and investors to understand the condition of a company. CFO turnover and internal financial controls play a large role in determining the quality of financial reporting. We investigated the association between CFO turnover and internal controls and found that companies with deficient internal controls are more likely to terminate their CFOs following financial restatements. Companies with deficient internal controls are also likely to have lower earnings quality. In this study, we further investigated how companies experiencing CFO turnover with weak internal controls can subsequently change controls to impact earnings quality.
\end{abstract}

Keywords: Internal control, CFO turnover, Earnings quality, Restatement 


\section{Introduction}

The Sarbanes-Oxley Act (SOX) aims to make major improvements to governance and financial reporting. A primary emphasis of the SOX is monitoring the role of CFOs in financial reporting, because they bear primary responsibility for the accuracy, documentation and submission of all financial reports. They also serve as the internal control structure to the SEC. CFOs thus play the first line of defense in monitoring the internal controls of financial reporting to ensure financial reporting quality, and the SOX imposes stringent civil and criminal penalties on negligent CFOs. Companies may terminate their CFO after accounting restatements to rebuild the internal controls of financial reporting. This raises the question of whether or not CFO turnover is more likely in companies with failures in internal controls of financial reporting, as these failures indicate negligence on the part of the CFOs. The purpose of this study is to examine company financial restatements to determine the relationship between CFO turnover and the internal controls of financial reporting for the company. We then examine the relationship between the earnings quality of companies with recently terminated CFOs and their internal control quality. Changes in internal control include upgrades or downgrades and may make various impacts on earnings quality.

Our results provide evidence that companies of deficient internal controls are more likely to terminate their CFOs following financial restatements. Such companies also have lower earnings qualities at the time of CFO turnover. This study focuses on specific CFO turnover cases and further considers a variety of internal control changes to examine the association between earnings quality and changes in internal control. Empirical results show that downgraded internal controls are associated with lower earnings quality, and vice versa.

Our study contributes to three important streams of research. First, it extends previous research into company internal controls. Second, this study contributes to literature on the association between changes in internal controls and earnings quality. Finally, this study provides important public policy implications, indicating that CFO turnover is an important signal of deficient internal controls, and such a signal implies that earnings quality is likely to be negatively impacted.

The remainder of this study is organized as follows: Section 2 presents a literature review. Section 3 describes the CFO turnover sample selection process and research design. Section 4 reports the empirical results. Conclusions are discussed in Section 5.

\section{Literature Review}

As the CFO has primary responsibility for a company's financial reporting quality, CFO turnover has generally received much attention from regulators as well as the public. In this section, we examine the literature to identify two topics of CFO turnover that are most relevant to this study.

\subsection{Internal Control Quality and CFO Turnover}

The quality of financial reporting is directly related to internal controls, which lies under the responsibility of the CFO. Prior studies find that financial statements may need to be restated 
due to errors resulting from deficient internal controls (Plumlee and Yohn 2010; Nagarajan and Carey 2008; Ashbaugh-Skaife et al. 2007; Grothe et al. 2007a; Grothe et al. 2007b; Hammersley et al. 2008; Li and Wang 2006). However, not every restatement resulted from deficient internal controls. Previous research has demonstrated that companies restating their earnings also have higher executive turnover (Burks 2010; Collins et al. 2009; Hennes et al. 2008; Arthaud-Day et al. 2006; and Desai et al. 2006), as well as higher director turnover (Srinivasan 2005). However, no systematic evidence exists on the relationship between internal control quality and CFO turnover. This raises the question of whether CFO turnover following restatements may be more likely in companies with failures in internal financial reporting controls, which indicate negligent CFOs.

\subsection{Internal Control Quality and Earnings Quality as Related to CFO Turnover}

Much of the research on internal controls focuses on the consequences of control failures (Plumlee and Yohn 2010; Hammersley et al. 2008; Nagarajan and Carey 2008; Li and Wang 2006). Few studies have investigated whether companies improve performance after these failures, which incur high costs and public criticism. Companies with failures in internal controls may have strong incentives to improve financial reporting quality and restore market confidence. Furthermore, prior research does not properly consider how changes in internal control systems contribute to control failures. Internal control deficiencies may be beneficial when they result from an upgrade in internal controls. For example, companies that move from weak to high-quality internal controls may have initial failures, but corporate performance ultimately improves.

It is generally acknowledged that companies that experience CFO turnover due to deficiencies in internal controls should prioritize improving future performance in internal control and earnings quality to restore financial statement credibility. However, there is little empirical research indicating that such companies actually improve. This study examines companies following internal control failure and related CFO turnover to determine whether earnings quality or internal controls improve following the acknowledgment of failure. We argue that failures in internal controls may actually offer an opportunity for companies to improve company performance through subsequent changes in internal controls.

\section{Research Design}

To test our research questions, we collected publicly listed companies in U.S. on an annual basis between November 2004 and December 2005, using probit and regression models. The following subsections reveal sources of research data and introduce our research model in detail.

\subsection{Data Sources}

First, we read proxy statements (Form DEF-14A) as well as press releases to identify CFO turnover of restating companies. If the proxy statement was not available, we searched for $10-$ Ks and 8-Ks. Since we were specifically studying restating companies, we defined CFO turnover as a CFO leaving a company following restatements. We do not consider it turnover if a manager leaves due to a company merger or acquisition. After identifying companies 
with CFO turnovers, we searched each firm's SEC file (e.g., 10-K, 10-K/A, etc.) from November 2004 through December 2005 for disclosure of any weaknesses in internal control. In the reports, we searched for the term "did not maintain effective internal control," a common indication of deficient controls used in audit reports. We hand-collected information on corporate governance (e.g., board size and audit committee independence) from the appointing companies' proxy statements (Form DEF-14A). Finally, we obtained accounting data from Standard and Poor's COMPUSTAT Annual Industrial, Research, and Full Coverage files.

\subsection{Model Specification - Internal Control Quality vs. CFO Turnover}

We constructed a research model to investigate whether CFO turnovers following restatements are associated with internal control weaknesses. The research model (1) is as follows:

$T U R N=\alpha_{0}+\alpha_{1} I C W+\alpha_{2} G R O W T H+\alpha_{3} L O S S+\alpha_{4} B I G N+\alpha_{5} S I Z E+\alpha_{6} B O A R D+\alpha_{7} I B O A R D+\varepsilon_{i, t}$

where TURN equals 1 if the CFO leaves the company following the restatement, else 0; ICW equals 1 if a company has weak internal controls, else 0; GROWTH equals one-year percentage increase in sales; LOSS equals 1 if operating income is less than zero, else 0 ; $B I G N$ equals 1 if the company's auditor is a Big N firm, else 0; SIZE equals the natural log of total assets; BOARD equals number of directors on the board; and IBOARD equals the number of independent directors on the board divided by the total board size.

\subsection{Model Specification - Internal Control Quality vs. Earnings Quality}

In cases of CFO turnover, we use equation (2) to estimate the association between internal control weaknesses and earnings quality. Our $D A$ variable as a measure of earnings quality is the performance matched discretionary accrual (Kothari et al. 2005). This figure is obtained by matching the two-digit SIC code of the company with the year and current return on assets. Further, equation (3) estimates the association between the changes of internal control quality and earnings quality. Models (2) and (3) are as follows:

$$
\begin{aligned}
D A=\alpha_{0} & +\alpha_{1} I C W+\alpha_{2} G R O W T H+\alpha_{3} L O S S+\alpha_{4} B I G N+\alpha_{5} S I Z E+\alpha_{6} B O A R D+\alpha_{7} I B O A R D+\varepsilon_{i, t} \\
D A=\alpha_{0} & +\alpha_{1} U P / D O W N / I C G G / I C B B+\alpha_{2} G R O W T H+\alpha_{3} L O S S+\alpha_{4} B I G N+\alpha_{5} S I Z E+\alpha_{6} B O A R D \\
& +\alpha_{7} I B O A R D+\varepsilon_{i, t}
\end{aligned}
$$

where UP equals 1 if the company improved their internal controls, else $0 ; D O W N$ equals 1 if the company's internal control has become weak, else 0; ICGG equals 1 if the company continues to maintain high-quality internal controls, else 0 ; ICBB equals 1 if the company 
continues to report weak internal controls, else 0 .

\section{Results and Analysis}

Table 1 presents the descriptive statistics for all variables used in our research models, partitioned by two subsamples: cases of companies with internal control weaknesses ( $\mathrm{n}=$ 114), and cases without internal control weaknesses $(n=174)$. As such, comparing two subsamples provides evidence as to whether or not CFO turnover following restatements is more likely to be associated with internal control weaknesses. The means (medians) of TURN and LOSS reported in the subsample with internal control weaknesses (ICW) are at the 0.01 level for both tests, which is significantly larger than those reported in the subsample with no internal control weaknesses. In addition, the means (medians) of BIGN and SIZE reported in the ICW subsample are at least at the 0.10 level for both, which is significantly smaller than those reported in the subsample without weaknesses. Univariate comparisons indicate that companies of internal control weaknesses have high CFO turnover (TURN), suffer more losses (LOSS), hire small auditors (BIGN), and are smaller in size (SIZE) than companies without internal control weaknesses. Overall, our findings suggest that CFO turnover of restating companies is likely to be associated with internal control weaknesses.

Table 1. Descriptive Statistics

\begin{tabular}{|c|c|c|c|c|c|c|}
\hline \multirow[b]{2}{*}{ Variables } & \multicolumn{2}{|c|}{$\begin{array}{c}\text { Internal Control } \\
\text { Weaknesses }(\mathrm{n}=114)\end{array}$} & \multicolumn{2}{|c|}{$\begin{array}{r}\text { No Internal Control } \\
\text { Weaknesses }(n=174)\end{array}$} & \multirow[t]{2}{*}{ t-test $^{1}$} & \multirow[t]{2}{*}{ Wilcoxon } \\
\hline & Mean & Median & Mean & Median & & \\
\hline TURN & 0.561 & 1.000 & 0.356 & 0.000 & $3.491^{* * *}$ & $3.425 * * *$ \\
\hline$D A$ & 0.205 & 0.010 & -0.252 & 0.000 & 1.205 & 0.061 \\
\hline GROWTH & 0.123 & 0.083 & 0.129 & 0.105 & -0.204 & -1.021 \\
\hline LOSS & 0.421 & 0.000 & 0.201 & 0.000 & $4.134^{* * *}$ & $4.022^{* * *}$ \\
\hline$B I G N$ & 0.825 & 1.000 & 0.902 & 1.000 & $-1.934 *$ & $-1.925 *$ \\
\hline SIZE & 6.613 & 6.481 & 6.899 & 7.064 & $-2.140 * *$ & $-2.227 * *$ \\
\hline$B O A R D$ & 8.281 & 8.000 & 8.598 & 9.000 & -1.186 & -0.996 \\
\hline IBOARD & 0.785 & 0.820 & 0.782 & 0.810 & 0.153 & 0.132 \\
\hline
\end{tabular}

${ }^{1}$ Asterisks *, **, *** indicate significance at the $0.10,0.05$, and 0.01 levels.

Table 2 represents the Pearson and Spearman correlations for the test and control variables used in the research models. Results show that $T U R N$ is positively correlated with ICW (0.202), implying that companies with internal control weaknesses are more likely to terminate their CFO. As depicted in this table, most explanatory variables are not significantly correlated to each other. We also estimate variance inflation factors (VIFs) to test for possible multicollinearity while considering all independent and control variables. None of the VIFs is greater than 1.8, indicating no presence of multicollinearity in our study. 
Table 2. Correlation Matrix

\begin{tabular}{|c|c|c|c|c|c|c|c|c|c|}
\hline Variables & TURN & $D A$ & ICW & $\begin{array}{c}\text { GROWT } \\
H\end{array}$ & LOSS & $B I G N$ & SIZE & BOARD & $I B O A R D$ \\
\hline TURN & & 0.006 & $0.202 *$ & $-0.143 *$ & $0.196 *$ & 0.025 & -0.066 & -0.052 & 0.108 \\
\hline$D A$ & -0.033 & & 0.004 & 0.024 & -0.034 & 0.050 & 0.057 & 0.015 & 0.047 \\
\hline ICW & $0.202^{*}$ & 0.071 & & -0.060 & $0.237^{*}$ & -0.114 & $-0.131^{*}$ & -0.059 & 0.008 \\
\hline GROWTH & -0.086 & 0.045 & -0.012 & & $-0.180 *$ & -0.081 & -0.081 & $-0.171 *$ & 0.051 \\
\hline LOSS & $0.196^{*}$ & -0.047 & $0.237 *$ & -0.096 & & $-0.168 *$ & $-0.175^{*}$ & -0.110 & $0.155^{*}$ \\
\hline$B I G N$ & 0.025 & 0.033 & -0.114 & -0.029 & $-0.168 *$ & & $0.408^{*}$ & $0.254^{*}$ & -0.095 \\
\hline SIZE & -0.061 & $0.126^{*}$ & $-0.126^{*}$ & -0.010 & $-0.165 *$ & $0.388 *$ & & $0.579 *$ & $-0.182 *$ \\
\hline$B O A R D$ & -0.068 & 0.023 & -0.070 & $-0.120^{*}$ & -0.094 & $0.255^{*}$ & $0.599 *$ & & $-0.228 *$ \\
\hline IBOARD & 0.111 & 0.073 & 0.009 & 0.091 & $0.153^{*}$ & -0.104 & $-0.130 *$ & $-0.221^{*}$ & \\
\hline
\end{tabular}

\footnotetext{
${ }^{\mathbf{1}}$ Pearson correlations in the lower diagonal and Spearman correlations in the upper diagonal. * Indicates significance at the 5
} percent level.

Panel A of Table 3 provides a breakdown of internal control quality and CFO turnover. As depicted in Panel A, the highest percentage of CFO turnover is present in the ICW subsample (22.22\%), confirming that companies with deficient internal controls have a higher probability of CFO turnover. We further document the results of CFO turnover regressed on internal control quality, with results demonstrated in Panel B of Table 3. As predicted, the coefficient on $I C W$ is 0.466 (significant at $\mathrm{p}<0.01$ ), suggesting once again that companies with deficient internal controls are more likely to terminate their CFOs following financial restatements. The coefficients on control variables (SALEGRW, LOSS, IBOARD) indicate that companies with better sales growth, fewer losses, and stronger corporate governance are associated with lower CFO turnover rates.

As discussed above, we find that companies of deficient internal controls are associated with higher rates of CFO termination. This lead to an exploration of the relationship between the earnings quality and internal control quality of companies with terminated CFOs, since earnings quality is the primary responsibility of CFOs. Column (1) of Table 4 indicates that the coefficient of $I C W$ is significantly positive. The coefficient of $I C W$ in column (2) is also significantly positive, while the coefficient of ICW in column (3) is positive, but not significant. These findings are consistent with our conjecture that companies of deficient internal controls have lower earnings quality in scenarios when CFOs are terminated due to financial restatements.

Table 4 shows empirical evidence for the relationship between earnings quality and internal control quality of companies with terminated CFOs. We considered a variety of internal control changes 


\section{Macrothink}

Table 3. Internal Control Weakness and CFO Turnover

\begin{tabular}{|c|c|c|c|c|}
\hline \multicolumn{5}{|c|}{ Panel A : Classification Table } \\
\hline & $\begin{array}{l}\text { Internal Control } \\
\text { Weaknesses }\end{array}$ & $\begin{array}{l}\text { No Internal Control } \\
\text { Weaknesses }\end{array}$ & & Total \\
\hline $\begin{array}{l}\text { No CFO } \\
\text { Turnover }\end{array}$ & $50(17.36 \%)$ & $112(38.89 \%)$ & & $162(56.25 \%)$ \\
\hline Turnover & $64(22.22 \%)$ & $62(21.53 \%)$ & & $126(43.75 \%)$ \\
\hline Total & $114(39.58 \%)$ & $174(60.42 \%)$ & & 288 \\
\hline \multicolumn{5}{|c|}{ Panel B : Result of Probit Analyses } \\
\hline Variables & Pred. Sign & Coef. & $z$-value ${ }^{1}$ & \\
\hline CONSTANT & & -0.996 & $-1.75^{*}$ & \\
\hline ICW & + & 0.466 & $2.90 * * *$ & \\
\hline GROWTH & - & -0.483 & $-1.46^{*}$ & \\
\hline LOSS & + & 0.413 & $2.32 * *$ & \\
\hline BIGN & ? & 0.388 & 1.59 & \\
\hline SIZE & ? & -0.012 & -0.22 & \\
\hline$B O A R D$ & + & -0.029 & -0.68 & \\
\hline IBOARD & + & 0.738 & $1.55^{*}$ & \\
\hline Pseudo $\mathrm{R}^{2}$ & & $6.51 \%$ & & \\
\hline Nobs. & 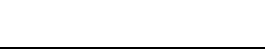 & 288 & & \\
\hline
\end{tabular}

Table 4. Internal Control Weakness and Earnings Quality of CFO Turnover

\begin{tabular}{|c|c|c|c|c|c|c|c|}
\hline \multirow{2}{*}{ Variables } & \multirow[b]{2}{*}{ Pred. Sign } & \multicolumn{2}{|c|}{ (1) } & \multicolumn{2}{|c|}{ (2) } & \multicolumn{2}{|c|}{ (3) } \\
\hline & & $\begin{array}{l}\text { Coef. } \\
t \text {-value }\end{array}$ & & $\begin{array}{l}\text { Coef. } \\
t \text {-value }\end{array}$ & & $\begin{array}{l}\text { Coef. } \\
t \text {-value }\end{array}$ & \\
\hline $\begin{array}{l}\text { CONSTAN } \\
T\end{array}$ & & -2.988 & -1.24 & -3.840 & -0.80 & -2.663 & -1.26 \\
\hline ICW & + & 0.657 & $1.55^{*}$ & 1.146 & $1.49 *$ & 0.244 & 0.72 \\
\hline GROWTH & + & 0.366 & 0.55 & 0.598 & 0.39 & 0.237 & 0.34 \\
\hline LOSS & - & -0.414 & -0.66 & -0.586 & -0.55 & -0.142 & -0.28 \\
\hline BIGN & - & -0.094 & -0.15 & -0.472 & -0.45 & 0.104 & 0.12 \\
\hline SIZE & ? & 0.320 & $1.73^{*}$ & 0.284 & 0.92 & 0.373 & 1.59 \\
\hline$B O A R D$ & - & -0.081 & -0.59 & -0.161 & -0.68 & -0.042 & -0.31 \\
\hline IBOARD & - & 1.651 & 1.02 & 3.813 & 1.04 & 0.361 & 0.30 \\
\hline Adj. $R^{2}$ & & $3.86 \%$ & & $6.13 \%$ & & $5.93 \%$ & \\
\hline Nobs. & & 288 & & 126 & & 162 & \\
\hline
\end{tabular}

${ }^{1}$ Asterisks $*,{ }^{* *}, * * *$ indicate significance at the $0.10,0.05$, and 0.01 levels, respectively. One-tailed for directional expectations, two-tailed for others.

(upgrades or downgrades) in our analyses, which may also make various impacts on earnings quality. Table 5 presents the regression results. Consistent with our expectations, the coefficients of ICW in columns (2) and (4) are significantly positive, suggesting that companies with internal control weaknesses that continued to have weak controls instead of upgrading are associated with lower earnings quality. On the contrary, the coefficient of ICW 
in column (3) is significantly negative, suggesting that companies that maintain high-quality internal controls are associated with higher earnings quality. However, the coefficient of ICW in column (1) showing companies that upgraded internal control measures is positive, but not significant, which is inconsistent with our expectations. A possible reason underlying this finding is that companies that upgraded internal control may need a period of adjustment to improve their earnings quality. Overall, these results confirm our expectations that even after CFO termination, internal control changes can make a heavy impact on earnings quality.

Table 5. Internal Control Changes (upgrade/downgrade) and Earnings Quality of CFO Turnover

\begin{tabular}{|c|c|c|c|c|c|c|c|c|c|}
\hline & & \multicolumn{2}{|c|}{ (1) } & \multicolumn{2}{|c|}{ (2) } & \multicolumn{2}{|c|}{ (3) } & \multicolumn{2}{|c|}{ (4) } \\
\hline Variables & $\begin{array}{l}\text { Pred. } \\
\text { Sign }\end{array}$ & $\begin{array}{r}\text { Coef. } \\
\text { t-value }^{1}\end{array}$ & & Coef. & $t$-value & Coef. & $t$-value & Coef. & $t$-value \\
\hline CONSTANT & & -3.240 & -0.70 & -3.252 & -0.70 & -2.620 & -0.61 & -3.913 & $-0.81 *$ \\
\hline$U P$ & - & 0.349 & 0.56 & & & & & & \\
\hline$D O W N$ & + & & & 1.224 & $1.89 * *$ & & & & \\
\hline$I C G G$ & - & & & & & -1.203 & $-1.58 *$ & & \\
\hline$I C B B$ & + & & & & & & & 1.158 & $1.30 *$ \\
\hline GROWTH & + & 0.883 & 0.53 & 0.900 & 0.54 & 0.601 & 0.39 & 0.842 & 0.53 \\
\hline LOSS & - & -0.362 & -0.36 & -0.316 & -0.31 & -0.576 & -0.54 & -0.545 & -0.51 \\
\hline$B I G N$ & - & -0.568 & -0.51 & -0.562 & -0.51 & -0.482 & -0.46 & -0.394 & -0.38 \\
\hline SIZE & ? & 0.271 & 0.88 & 0.272 & 0.90 & 0.293 & 0.94 & 0.252 & 0.89 \\
\hline BOARD & - & -0.155 & -0.63 & -0.162 & -0.64 & -0.167 & -0.71 & -0.148 & -0.61 \\
\hline IBOARD & - & 3.689 & 1.01 & 3.825 & 1.03 & 3.723 & 1.03 & 4.276 & 1.11 \\
\hline Adj. $R^{2}$ & & $4.15 \%$ & & $4.15 \%$ & & $6.36 \%$ & & $5.61 \%$ & \\
\hline Nobs. & & 126 & & 126 & & 126 & & 126 & \\
\hline
\end{tabular}

${ }^{1}$ Asterisks *,**,*** indicate significance at the $0.10,0.05$, and 0.01 levels, respectively. One-tailed for directional expectations, two-tailed for others.

\section{Conclusions}

This paper provides empirical evidence regarding the relationship between internal controls and CFO turnover based on a sample of 288 restating companies from 2004 to 2005. Overall, evidence shows that companies with deficient internal controls are more likely to terminate their CFOs following financial restatements. CFO turnover observations further indicate that even after CFO termination, subsequent changes in internal controls have an impact on earnings quality. Downgraded internal controls are associated with lower earnings quality, while improved internal controls are associated with higher earnings quality. 
One major limitation of our study is that the sample period was only two years, due to manual collection of data on internal controls and CFO turnover via reading proxy statements. Future research can explore whether and how restating companies with initial weak internal controls can improve their reputations by signaling improved financial reporting quality in the post-restatement era. We know that prior research uses various measures of corporate reputation, but America's Most Admired Companies List is by far the most widely used measure (Highhouse et al. 2009; Riahi-Belkaoui 2001; Flanagan and O’Shaughnessy 2005; Fombrun and Shanley 1990). Researchers can use America's Most Admired Companies List as a proxy for corporate reputation.

\section{References}

Arthaud-Day, M. L., Certo, S. T., Dalton, C.M., \& Dalton, D. R. (2006). A changing of the guard: executive and director turnover following corporate financial restatements. Academy of Management Journal, 49, 1119-1136. http://dx.doi.org/10.5465/AMJ.2006.23478165

Ashbaugh-Skaife, H., Collins, D., \& Kinney, W. (2007). The discovery and reporting of internal control deficiencies prior to SOX-mandated audits. Journal of Accounting and Economics, 44, 166-192. http://dx.doi.org/10.1016/j.jacceco.2006.10.001

Burks, J. T. (2010). Disciplinary measures in response to restatements after Sarbanes-Oxley. Journal of Accounting and Public Policy, 25, 121-139.

Collins, D., Masli, A., Reitenga, A.L., \& Sanchez, J. M. (2009). Earnings restatements, the Sarbanes-Oxley Act and the disciplining of chief financial officers. Journal of Accounting, Auditing \& Finance, 24, 1-34.

Desai, H., Hogan, C., \& Wilkins, M. S. (2006). The reputational penalty for aggressive accounting: earnings restatements and management turnover. The Accounting Review, 81, 83-112. http://dx.doi.org/10.2308/accr.2006.81.1.83

Flanagan, D. J., \& O’Shaughnessy, K. C. (2005). The effects of layoffs on firm reputation. Journal of Management, 31(3), 445-463. http://dx.doi.org/10.1177/0149206304272186

Fombrun, C. J., \& Shanley, M. (1990). What's in a name? Reputation building and corporate strategy. Academy of Management Journal, 33(2), 233-258. http://dx.doi.org/10.2307/256324

Grothe, M., Goodwin, J., Iandera, O., Laurion, H., \& Freeland, J. (2007a). The materially weak. Yellow Card Trend Alert. Glass Lewis \& Co., LLC.

Grothe, M., Saban, J., Plachecki, M., Lee, R., \& Post, B. (2007b). The errors of their ways. Yellow Card Trend Alert. Glass Lewis \& Co., LLC.

Hammersley, J., Myers, L., \& Shakespeare, C. (2008). Market reactions to the disclosure of internal control weaknesses and to the characteristics of those weaknesses under Section 302 of the Sarbanes-Oxley Act of 2002. Review of Accounting Studies, 13, 141-165. http://dx.doi.org/10.1007/s11142-007-9046-z

Hennes, K. M., Leone, A. J., \& Miller, B. P. (2008). The importance of distinguishing errors 


\section{Macrothink}

Asian Journal of Finance \& Accounting

ISSN 1946-052X

2013, Vol. 5, No. 1

from irregularities in restatement research: The case of restatements and CEO/CFO turnover. The Accounting Review, 83, 1487-1519.

Highhouse, S., Broadfoot, A., Yugo, J. E., \& Devendorf, S. A. (2009). Examining corporate reputation judgments with generalizability theory. Journal of Applied Psychology, 94(3), 782-789. http://dx.doi.org/10.2308/accr.2008.83.6.1487

Kothari, S. P., Leone, A. J., \& Wasley, C. (2005). Performance matched discretionary accrual measures. Journal of Accounting and Economics, 39, 163-197. http://dx.doi.org/10.1016/j.jacceco.2004.11.002

Li, C., \& Wang, Q. (2006). SOX 404 assessments and financial reporting errors. Working paper, University of Pittsburgh and Iowa State University.

Nagarajan, R., \& Carey, P. (2008). Effectiveness of internal control over financial reporting and financial statement restatements: The role of management. Working paper, Monash University Australia.

Plumlee, M. A., \& Yohn, T. L. (2010). An analysis of the underlying causes attributed to restatements. Accounting Horizons, 24, 41-64. http://dx.doi.org/10.2308/acch.2010.24.1.41

Riahi-Belkaoui, A. (2001). Contextual accrual and cash flow based valuation models: Impact of multinationality and corporate reputation. Advances in Financial Planning and Forecasting 10: 25-35.

Srinivasan, S. (2005). Consequences of financial reporting failure for outside directors: Evidence from accounting restatements and audit committee members. Journal of Accounting Research, 43, 291-334. http://dx.doi.org/10.1111/j.1475-679x.2005.00172.x 